\title{
IDENTIFIKASI KOMPONEN SENYAWA KIMIA EKSTRAK BIJI BUAH NAGA MERAH (Hylocereus polyrhizus) SEBAGAI BAHAN BAKU INDUSTRI
}

\section{THE IDENTIFICATION OF CHEMICAL COMPOUNDS COMPONENTS OF RED DRAGON SEED EXTRACT (Hylocereus polyrhizus) AS INDUSTRIAL RAW MATERIALS}

\author{
Eldha Sampepana, Titik Nurwidayati, Suroto HS \\ Balai Riset dan Standardisasi Industri Samarinda \\ Jl. MT. Haryono/Jl. Banggeris No. 1 Samarinda, \\ Telp. 0541-7771364/ Fax. 0541745431 \\ Email : dha_spana@yahoo.com
}

Diterima : 22-11-2019

Direvisi : 04-12-2019

Disetujui : 23-12-2019

\begin{abstract}
ABSTRAK
Biji buah naga merah merupakan limbah padat industri olahan buah naga yang belum termanfaatkan namun diduga memiliki senyawa kimia yang bermanfaat maka dilakukan penelitian dengan tujuan untuk mengidentifikasi komponen senyawa kimia ekstrak biji buah naga merah sebagai bahan baku industri. Metode yang digunakan adalah ekstraksi secara maserasi ekstrak biji buah naga merah dengan pelarut etanol dan n-Hexan kemudian dianalisa menggunakan Gas Cromatografi Mass Spektrofotometer (GCMS). Hasil penelitian menunjukkan bahwa proses ekstraksi secara maserasi menggunakan pelarut $n$-Hexan lebih banyak menghasilkan komponen senyawa kimia dibandingkan dengan pelarut etanol. Komponen senyawa kimia yang larut pada pelarut etanol terdapat 24 senyawa dan yang dominan ada 9 senyawa yang dapat digunakan sebagai bahan baku industry seperti2-Pyridinepropanoic acid $\alpha$-methyl- $\beta$-oxo-ethyl ester, 1-Propanol,2-amino-(CAS) 2-Amino-1-, $\alpha, \alpha, 3,3$-tetramethylpiperidinepe. Sedangkan senyawa kimia pada pelarut $n$-Hexan terdapat 250 senyawa kimia dan yang paling domina nada 34 senyawa yaitu hexadecanoid acid, octadec-9-enoic acid, etil linoleat 9-octadecenoic acid (Z)-(CAS) methyl ester, 2,4Decadienal, (E,E)-(CAS) trans, trans-2,4-Decadienal, 2- $\beta$-PINENE, 1-Octen-3-ol, $\alpha$-Bergamotene, $\beta$ Bisabolene.Senyawa kimia tersebut merupakan senyawa volatil, esensial oil, turunan asam lemak, vitamin, obat-obatan, antioksidan, antibakteri yang digunakan sebagai sumber bahan baku industry ipangan, kosmetik, farmasi.
\end{abstract}

Kata Kunci : komponen senyawa kimia, etanol, bahan baku industri, n-Hexan, biji buah naga merah.

\section{ABSTRACT}

Red dragon fruit seeds are solid waste processed dragon fruit industry that has not been exploited but is suspected to have chemical compounds. Hence, this research aimed to identify the chemical compounds components Red dragon Seed extract as an industrial raw material was conducted. The method used wasthe maceration of the extracted red Dragon fruit seed extract with ethanol and n-Hexan extracts and then analysed using Gas Cromatography Mass Spectrophotometer (GCMS). The results showed that maceration of the extraction process using nHexan solvent produces more chemical components than the ethanol solvent. Components of chemical compounds that dissolve in the ethanol solvent there were 24 compounds and there were 9 dominant compounds that can be used as industrial raw materials such as 2-Pyridinepropanoic acid $\alpha$-methyl- $\beta$-oxo-ethyl ester, 1-Propanol,2-amino-(CAS) 2Amino-1-, $\alpha, \alpha$, 3,3-tetramethylpiperidinepe. On the other hand, there were 250 chemical compounds in the $\mathrm{N}$-Hexan solvent and there were34 most dominant compounds namely hexadecanoid acid, octadec9-enoic acid,etillinoleat, 9-octadecenoic acid (Z)-(CAS) methyl ester, 2,4-Decadienal, (E,E)-(CAS) trans, trans-2,4-Decadienal, 2- $\beta$-PINENE, 1-Octen-3-ol, $\alpha$-Bergamotene, $\beta$-Bisabolene. These chemical compounds were volatile compounds, essential oils, fatty acid derivatives, vitamins, medicines, 
antioxidants, antibacterial used as a source of raw materials for food industry, cosmetics, pharmaceuticals.

Keywords : chemical compounds components, ethanol, industrial raw material, n-Hexan, Red dragon fruit seeds

\section{PENDAHULUAN}

D enggunaan bahan baku industri, bahan penolong di Indonesia masih mengandalkan bahan kimia yang diimpor dari luar negeri sebesar 64\% sehingga industry nasional mengalami gejolak fluktuasi kurs rupiah terhadap dolar Amerika Serikat (Bukhari, 2014). Ketergantungan bahan baku import dalam menghadapi permasalaahan ini dengan mempercepat proses hilirisasi yaitu meminimalisasi ketergantungan bahan baku impor dengan kembali memanfaatkan sumber alam baik berupa akar, batang, daun, biji, buah, kulit kulit tanaman.

Pemanfaatan biji buah naga merah merupakan salah satu cara dalam mengatasi ketergantungan bahan baku impor. Biji buah naga merah(Hylocereus polyrhizus) merupakan salah satu limbah padat pada industry olahan buah naga merah karena dapat merusak penampilan produk sehingga tidak dimanfaatkan.

Dari hasil penelitian Murugesu et al, (2013) menyebutkan bahwa biji buah naga merah berwarna hitam yang berlapis lender memiliki minyak biji buah naga merah yang mengalami proses ekstraksi dengan menggunakan pelarut air panas dan air dingin mengandung senyawa asam-asam lemak seperti palmitat, oleat dan asam linoleat. Sedangkan Chemahet al, (2011) mengungkapkan bahwa kandungan lemak pada biji buah naga merah $(22,8 \%)$ lebih besar dari pulp buah naga merah $(0,1 \%)$. Selain itu biji buah naga mengandung proksimat seperti kadar protein 26,3 g, oil 22,8 g, abu $61 \mathrm{~g}$ dan karbohidrat 44,8 g (Chemah, 2010). Raihana et al, (2015) dalam hasil penelitiannya mengungkapkan bahwa biji buah naga mengandung fitonutrien, protein sebesar 6-40\% yang dapat dikonsumsi dan digunakan sebagai obat.

Penelitian Adnan (2011) menyatakan bahwa "biji buah naga merah yang diekstrak dengan menggunakan pelarut etanol, n-Hexan dan kloroform mengandung senyawa kimia flavonoid yang sangat dominan". Biji buah naga merah juga mengandung senyawa asam linoleat 98,90\%, fenolik, asam askorbat catekin dan flavonoid.Senyawa flavonoid berfungsi sebagai antioksidan, antimikroba, antivirus, anti kanker (Arukwe et al., 2012).

Chemahet al. (2010) mengungkapkan total fenolik dan flavonoid biji buah naga merah kering per $100 \mathrm{~g}$ berat kering dikategorikan tinggi yaitu 43,9 mg GAE dan 50,8 mg CAE, aktivitas antioksidannya sangat kuat, mengandung asam lemak yaitu asam palmitat (C16:0), Stearat (C18:0), oleic (C18:1), Linoleat (C18:2), asam linoleat sebesar $480 \mathrm{~g} / \mathrm{kg}$. Arifin et al, (2009) dalam Nurul et al (2014) dalam hasil penelitiannya menjelaskan bahwa asam lemak esensial pada buah naga putih (Hylocereus undatus) dan buah naga merah (Hylocereus polyrhizus) sebesar 50\% yang terdiri dari $48 \%$ C18:2 dan 1,5\% C18:3.

Senyawa asam lemak tersebut pada umumnya digunakan pada industry pangan, kosmetik dan farmasi. Selain itu biji buah naga merah apabila dipecahka nmenimbulkan aroma yang khas yang diduga memiliki beberapa senyawa kimia yang bermanfaat sebagai bahan baku industry farmasi, kosmetik dan pangan. Senyawa kimia tersebut dapat diperoleh melalui proses ekstraksi dengan menggunakan pelarut organik polar dan non polar maka dilakukan penelitian dengan tujuan identifikasi komponen senyawa kimia ekstrak biji buah naga merah (hylocereus polyrhizus) sebagai bahan baku industri.

\section{METODE PENELITIAN}

\section{Bahan dan Alat yang digunakan}

Bahan yang digunakan adalah biji buah naga merah yang diperoleh dari limbah penelitian konsentrat sari buah naga, air PDAM, kertas saring, n-Hexan, etanol, aquades. Sedangkan alat 
yang digunakan terdiri dari baskom, saringan, tampah, blender, crusher 80 mess, corong pisah, erlenmeyer, gelas beaker, gelas ukur, botol ekstrak, tabung reaksi, botol sampel, shaker, neraca analitik, mikropipet, oven, rotovapor, gas chromotografy massa spectrophotometer (GCMS)

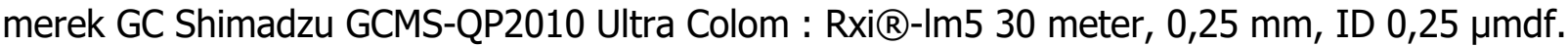
Data library Wiley7.LIB.(338,323 Spectrum).

\section{Penyiapan Biji Buah Naga Merah}

Biji buah naga merah dari penelitian olahan konsentrat sari buah naga merah dimasukkan kedalam saringan kemudian dicuci dengan mengalirkan air PDAM secara terus menerus hingga bersih lalu ditiriskan dan dikeringkan menggunakan oven pada suhu $50^{\circ} \mathrm{C}$ hingga kering \pm 2 (dua) hari. Selanjutnya diblender hingga menjadi halus kemudian di ayak dengan menggunakan ayakan dengan ukuran 80 mesh lalu disimpan dalam toples.

\section{Proses Ekstraksi Biji Buah Naga Merah}

Proses ekstraksi biji buah naga merah dilakukan dengan menggunakan bubuk biji buah naga sebanyak $50 \mathrm{~g}$ dimasukkan kedalam kedua buah botol ekstrak yaitu botol ekstrak pertama dan botol ekstrak kedua. Botol pertama ditambahkan dengan pelarut etanol dan botol ekstrak kedua ditambahkan dengan pelarut n-Hexan. Kedua buah botol ekstrak tersebut di shaker selama 2 (dua) jam lalu di maserasi selama 24 (dua puluh empat) jam. Setelah dimaserasi, larutan tersebut dipisahkan dengan cara disaring dan selanjutnya dipisahkan dengan pelarut dengan cara menguapkan pelarut tersebut menggunakan rotary evaporator hingga membentuk pasta. Pasta ekstrak biji buah naga merah dianalisis komponen senyawa kimia organik yang aktif dalam ekstrak biji buah naga merah dengan menggunakan (GCMS) merek GC Shimadzu GCMS-QP2010 Ultra Colom: Rxiß-Im5 30meter, 0,25 mm, ID 0,25 $\mu$ mdf. Data library Wiley7.LIB.338,323 Spectrum. Data yang diperoleh berupa komponen senyawa kimia secara GCMS dianalisis secara deskriptif

\section{HASIL DAN PEMBAHASAN}

Komponen Senyawa Kimia Ekstrak Biji Buah Naga Merah (Hylocereus polyrhizus) pada pelarut etanol terdapat 24 komponen senyawa kimia dan yang paling dominan ada 9 (sembilan) senyawa, sedangkan komponen senyawa kimia ekstrak biji buah naga merah dengan pelarut nHexanterdapat 250 senyawa kimia dan yang paling dominan ada 34 senyawa yang dapa tdilihat pada Tabel 1.

Tabel 1. Komponen Senyawa Kimia OrganikEkstrak Biji Buah Naga Merah (Hylocereus polyrhizus) dengan pelarut etanol dan n-Hexan (Data Primer, 2016)

\begin{tabular}{|c|c|c|c|}
\hline $\begin{array}{c}\text { Jenis } \\
\text { Pelarut }\end{array}$ & Komponen Senyawa Kimia & $\%$ Area & SI \\
\hline \multirow[t]{9}{*}{ Etanol } & 2-Pyridinepropanoic acid $\alpha$-methyl- $\beta$-oxo-ethyl ester & 0,01 & 92 \\
\hline & 1H-Pyrrole, 2,5-dihydro-1-nitroso-(CAS) Nitroso-3-pyrroline & 0,05 & 64 \\
\hline & 1,2-DIETHYLDIBORANE-D14 & 0,03 & 56 \\
\hline & 1-Propanol,2-amino-(CAS) 2-Amino-1- & 0,06 & 78 \\
\hline & Ethyl N-methylcarbamate & 0,02 & 50 \\
\hline & $\alpha, \alpha, 3,3$-tetramethylpiperidinepe & 0,01 & 58 \\
\hline & Phosphonothioic acid, ethyl-, O-ethyl S- & 0,02 & 31 \\
\hline & $\begin{array}{l}\text { (Z)-1-ethhoxycarbonyl-1-fluro-2-(methoxycarbonyl)-1,3- } \\
\text { butadiene }\end{array}$ & 0,07 & 91 \\
\hline & Carbamic acid, methyl ester (CAS) methyl & 0,01 & 83 \\
\hline
\end{tabular}




\begin{tabular}{|c|c|c|c|}
\hline \multirow[t]{34}{*}{ n-Hexan } & Hexadecanoid acid, ethyl ester & 15,84 & 83 \\
\hline & Hexadecanoid acid (CAS) Palmitic acid & 14,23 & 87 \\
\hline & Octadec-9-enoic acid & 14,17 & 71 \\
\hline & 1,10-Decanediol (CAS) Decane-1,10-diol & 9,71 & 83 \\
\hline & Ethyl linoleate & 9,14 & 87 \\
\hline & 3a,7a-Epoxy-1H-inden-1-one,hexahydro (CAS) & 7,12 & 87 \\
\hline & 9-octadecenoicacid (Z)-(CAS) methyl ester & 4,55 & 87 \\
\hline & 9-Octadecenoic acid (Z)-ethyl ester (CAS) & 4,33 & 78 \\
\hline & 2-Cyanato Methyl Cyclohexane & 3,02 & 69 \\
\hline & dl-Limonene & 1,40 & 94 \\
\hline & Hexanal (CAS) n-Hexanal & 1,16 & 98 \\
\hline & Tetradecanoic acid (CAS) myristic acid & 0,84 & 95 \\
\hline & Lycopersen & 0,74 & 93 \\
\hline & Vinyl-2,6,8-trimethyl-4-nonyl ether & 0,49 & 83 \\
\hline & 9-Octadecenoic acid (Z)-(CAS) oleic acid & 0,45 & 88 \\
\hline & 2,4-Decadienal, $(\mathrm{E}, \mathrm{E})$-(CAS) trans, trans-2,4-Decadienal & 0,43 & 95 \\
\hline & Benzene, 1-methyl-4-(1-methylethyl)- & 0,40 & 96 \\
\hline & 9-octadecenoic acid (Z)-, hexadecyl ester & 0,36 & 90 \\
\hline & Octanoic acid (CAS) Caprylic acid & 0,34 & 87 \\
\hline & 9,12-octadecadienoic acid $(\mathrm{Z}, \mathrm{Z})$-, methyl ester & 0,34 & 93 \\
\hline & $\begin{array}{l}\text { 9-octadecenoic acid (Z)-, 9-hexadecenyl ester, (Z)- (CAS) } \\
\text { 9-Cis-Hexadecenyl 9-Cis-Octadecenoate }\end{array}$ & 0,25 & 82 \\
\hline & 2-Dodecenal (CAS) 2-Dodecen-1-al & 0,28 & 81 \\
\hline & Dodecanoic acid (CAS) Lauricacid & 0,27 & 95 \\
\hline & Octanoic acid, 8-hydroxy-(CAS) 8-Hydro & 0,24 & 91 \\
\hline & $\beta$-Bisabolene & 0,20 & 94 \\
\hline & 2- $\beta$-Pinine & 0,10 & 95 \\
\hline & Trans-Carveol & 0,10 & 91 \\
\hline & $\alpha$-Bergamotene & 0,16 & 93 \\
\hline & Neryl acetate & 0,14 & 87 \\
\hline & 2-Decanal, (E)-(CAS) trans-2-Decanal & 0,12 & 81 \\
\hline & $\beta$-pinenoxid & 0,05 & 86 \\
\hline & Junipene & 0,03 & 89 \\
\hline & $\begin{array}{l}\text { 2,6,10,14,18,22-tetracosahexaene,2,6,10,15,19,23- } \\
\text { hexamethyl-(CAS) Squalene }\end{array}$ & 0,02 & 90 \\
\hline & Bicyclo $[3,1,1]$ heptan-3-ol, 6,6-dimethyl-2 & 0,01 & 70 \\
\hline
\end{tabular}

Selain komponen kimia pada tabel 1 terdapat dugaan senyawa minim dari 24 senyawa yang larut pada pelarut etanol adalah senyawa 2,4-dicloro-2,4-difloro-1,3-dithiethane-1,1,3,3tetraoxide, 1-propanol-1-D1, Glycine D3, 2-Isobutyl-4,4-dimethyl-1,3-dioxane, Oxygen, Acetaldehyde, hydroxyl-(CAS) glycolaldehyde, 1-propanol,2-amino-(CAS) 2-amino-1-propanol yang merupakan salah satu senyawa volatile, asam asetat. Menurut Wartini et al. (2010) bahwa senyawa volatil dapat bermanfaat sebagai bahan flavor dan insektisida (Wonorahardjo, 2015).

Sedangkan dugaan senyawa minim dari 250 senyawa yang larut pada pelarut $n$-Hexan adalah senyawa $\alpha$-Tecopheryl- $\beta$-D-Mannosid dengan tingkat kemiripan sebesar Vitamin E $91 \%$, 2,2'-biquinoline, $\alpha$-Tecopheryl- $\beta$-D-Mannosid 92\%, Vitamin E 91\%, 2,2'-biquinoline, psi.psi.carotene, $7,7,8,8^{\prime} .11,11^{\prime}, 12,12^{\prime}, 15,15^{\prime}$-decahydro(CAS) Lycopersene yang berfungsi sebagai bahan antioksidan, antimikrobiologi, vitamin yang digunakan sebagai bahan baku untuk industri pangan, farmasi dan kosmetik. 
Berdasarkan pada tabel 1 menunjukkan bahwa komponen senyawa kimia ekstrak biji buah naga merah dengan pelarut $\mathrm{n}$-Hexan lebih banyak dibandingkan dengan menggunakan pelarut etanol. Hal ini menunjukkan bahwa senyawa kimia yang larut pada pelarut etanol selama proses ekstraksi adalah senyawa polar, sedangkan senyawa kimia yang larut dalam pelarut $\mathrm{n}$-Hexan adalah senyawa kimia non polar. Hal ini sama diungkapkan oleh Guenther (1987) dalam Susanti et al. (2012) menyebutkan bahwa "kepolaran suatu pelaru tsangat berpengaruh terhadap senyawa kimia yang larut atau terdekomposisi pada proses ekstraksi sehingga senyawa kimia polar larut dalampelarut polar (etanol) dan senyawakimia non polar larutdalampelarut non polar (n-Hexan)".

Tabel 1 menujukkan komponen senyawa kimia pada ekstrak biji buah naga merah menggunakan pelarut n-Hexan diperoleh senyawa asam lemak (palmitat, oleicacid, linoleate), Hal tersebut sama diungkapkan oleh Chemah (2010) bahwa ekstrak biji buah naga merah mengandung asam lemak seperti linoleat, palmitat. Arifin et al. (2009) yaitu ekstrak biji buah naga merah memiliki senyawa asam linoleat dan asam linoleat.

Menurut Susmitha et al (2014) bahwa "senyawa octadecanoid acid, tetradecanoid acid, 9,12,15-octadecatrienoic acid,10,6,10 dan nanonoic acid pada rentention time 9,454 berfungsi sebagai anti-constipation, anti inflamasi, antivirus, immunosuppressant antimicrobial, anticancer, hepatoprotective, anti-arthritic, anti-asthama, diuretic.anti-malarial, anti-dengue, anti-filariasis, antimicrobial". Hexadecanoid acid dapat digunakan sebagai antioksidan, menurunkan kolesterol dan hemolisa (Suryowati et al., 2015). Uma et al. (2011), senyawa Octadecadienoic acid berfungsi melindungi sel $\beta$-pankareas. Senyawa Carbamic acid, methyl ester (CAS) methyl berfungsi sebagai antimikroba.

Menurut zat penghambat Abdullah et al. (2019) bahwa senyawa ester ekstrak biji buah naga merah melalui proses hidrolisis dan alkalosis mengandung $42,36 \%$ oley linoleate; $22,64 \%$ oley oleate; $14,31 \%$ oley palmitat dan 3,17\% oley stearat. Sedangkan Murugesu etal. (2013), senyawa kimia ekstrak biji buah naga merah dengan pelarut air panas dan air dingin menghasilkan senyawa kimia antara lain: senyawa myristik, palmitat, palmitoloic, stearic, oleic, Cis-Vaccenic, linoleat, linoleic dan erucicacid. Raihana (2015) menyebutkan bahwa komponen senyawa tersebut banyak digunakan sebagai bahan baku atau bahan penolong pada industri pangan, kometik dan farmasi.

Sholehah (2010), kematangan sebuah buah sangat mempengaruhi komponen senyawa kimia yang ada dikandungnya; kadar lemak, protein kadar air, abu, dan pH (Tarigan dan Towah, 2017) kandungan total gula, serat dan $\beta$-karoten (Sarungalloet al., 2018).

\section{KESIMPULAN}

Komponen senyawa kimia ekstrak biji buah naga merah yang terdapat pada pelarut nHexan yaitu 250 senyawa dan 34 senyawa yang dominan, pelarut etanol 24 senyawa kimia dan yang dominan 9 senyawa kimia. Senyawa kimia terdiri dari volatil, esensial oil, turunan asam lemak, vitamin, obat-obatan, antioksidan, antibakteri yang merupakan sumber bahan baku industri pangan, kosmetik, farmasi.

\section{DAFTAR PUSTAKA}

Abdullah, A.,Gani S. S. A., Hin, T.Y.Y., 2019.Lipase-Catalyzed Synthesis of Red Pitaya (Hycocereus polyrhizus) Seed Oil Esters for Cosmeceutical Applications: Process Optimization Using Response Surface Methodology. Royal Society of Chemistry Advance 9. Pp. 5599-5609.

Adnan, L., Osman, A.dan Hamid, A. A. 2011. Antioxidant Activity of Different Extracts of Red Pitaya (HylocereusPolyrhizus) Seed. International Journal of Food Properties 14. pp. 11711181. 
Arifin, A.A., Jamilah, B., Tan, C.P., Russly, A.A., Roselina, K. and Loi, C.C. 2009. Essential fatty Acids of Pitaya (Dragon Fruit) Seed Oil. Food Chemistry 114:561-564.

Arukwe, B.A., M.K. Duru, E.N. Agomuo dan Adindu, E.A.2012. Chemical Composition of Persea Americana Leaf, Fruit and Seed.International Journal of Recent Research and Applied Studies. 11 (2): 346-349.

Bukhari, A. 2014. 64\% dari Industri Nasional Bergantung pada Bahan Baku Impor. Indonesia Financie Today Kementerian Perindustrian. https://kemenperin.go.id/artikel/9306/64dari-industri-nasional-bergantung-pada-bahan-baku-impor. Akses 21-06-2019.

Chemah, T.C., Aminah, A., Noriham, A. and Wan,A., W.M. 2010. Determination of pitaya seeds as a natural antioxidant and source of essential fatty acids. International Food Research Journal 17. pp. 1003-1010.

Chemah, T.T., Sabaianah, B. and Noradzahar, B. 2011. Quality characteristics and acceptability of three types of pitaya fruits in a consumer acceptance test. Journal of Tourism, Hospitality \& Culinary Arts 3 (98):89-98

Gutièrret, M.G.V., Schweiggert, R.M., Carle, R., Esquive P., 2012. Chemical Characterization of Central American Pitaya (Hylocereus SP.) Seeds and Seed Oil.CyTA Journal of Food Volume 10 No. 1 Februari.Taylor\& Francis Group. pp. 78-83.

Murugesu, S., Ariffin A.A., Ping T. C., 2013. Physicochemical Properties of Oil Extracted from The Hot and Cold Extracted Red Pitaya (Hylocereuspolyrhizus) Seeds. Journal of FoodChemistry and Nutrition. ISSN: 2307-4124, pp. 78-83.

Nurul, S.R. and Asmah, R. 2014. Variability in nutritional composition and phytochemical properties of red pitaya (Hylocereus polyrhizus) from Malaysia and Australia. International Food Research Journal 21(4): 1689-1697. PP. 1689-1697.

Raihana, A.R.N., Marikkar, J.M.N., Amin,I. Dan Shuhaimi, M. 2015. A Review on Food Values of Selected Tropical Fruits' Seeds. International Journal of Food Properties,18:2380-2392, 2015.

Sarungallo, Z.L., Susanti, C.M.E., Sinaga, N. I., Irbayanti, D.N., Latumahina, R.M.M., 2018. Kandungan Gizi Buah Pandan Laut (Pandanus tectorius Park.) Pada Tiga Tingkat Kematangan. Jurnal Aplikasi Teknologi Pangan 7 (1).

Sholehah,D.N. 2010.Pengukuran Kandungan Skopoletin pada Beberapa Tingkat Kematangan Buah Mengkudu (MorindacitrifollaLinn) dengan Metode KLT Densitometri. Agrovigor Volume 3 No.1 Maret. 1-9.

Suryowati, T., Rimbawan, Damanik, R., Bintang, M., Handharyani, E., 2015.Identifikasi Komonen Kimia dan Aktivitas Antioksidan DalamTanaman Torbangun (Coleus amboinicusLour). Jurnal Gizi Pangan, Volume 10, Nomor3, November. 217-224.

Susanti, A. D., Adiana, D., Gumelar, P. G., Bening, Y.2012. Polaritas Pelarut sebagai Pertimbangan Dalam Pemilihan Pelarut Untuk Ekstraksi Minyak Bekatul dari Varietas Ketan (Oriza Sativa Glatinosa). Simposium Nasional RAPI XI UMS-2012. pp 1-7. ISSN1412-9612

Sushmitha, H.S, Laha, R. C., Gogoi, D., Velagala, R.D., Amresh, N., Sathyamurthy, B., and Rajadurai, M., 2014. Phytochemical and Pharmacological Studies on Hylocereus undatus Seeds: An In Vitro Approach. World Journal of Pharmaceutical Research SJIF Impact factor 8.074. Volume 7, Issue 14, 986-1006. ISSN 2277-7105.

Tarigan, E. B. dan Towaha, J. 2017. Pengaruh Tingkat Kematangan Buah, Serta Lama Fermentasi dan Penyangrai Biji Terhadap Karakter Fisikokimia Kopi Robusta. Jurnal Tanaman Industri dan Penyegar Volume 4, Nomor 3, November.pp.21-26.

Uma,M., Jothinayaki, S., Kumaravel,S., Kalaiselvi, P. 2011. Determination of bioactive components of pleectranthu sambonicus Lour by GC-MS Analysis. New York Science J. http://www.sciencepub.net/newyoork. 
Wartini, N.M., Ina, P.T., Putra, G.P.G. 2010. Perbedaan Kandungan Senyawa Volatil Daun Salam (Eugenia polyantha Wight) Pada Beberapa Proses Curing. Agritech, Vol. 30, No. 4, November. 231-236

Wonorahardjo,S., Nurindah, Sunarto,D. A., Sujak, Zakia,N. 2015. Analisis Senyawa Volatil dari Ekstrak tanaman yang berpotensi sebagai atraktan parasitoid telur wereng batang coklat, Anagrusnilaparvatae (Pang et Wang) (Hymenoptera:Mymaridae). Jurnal Entimologi Indonesia Volume 12, No. 1, Maret, 48-57. DOI:10.5994/jei.12.1.48 